\title{
Value of Child-Turcotte-Pugh Score in Prediction of Treatment Response in "Difficult to Treat" Chronic HCV Cirrhotic Patients
}

\author{
Taghrid Mohamed Abdalla ${ }^{\circledR}$, Sameh M. Abdel Monem ${ }^{(0)}$, Hosam M. Dawod ${ }^{*}$ (] \\ Tropical Medicine Department, Faculty of Medicine, Zagazig University, Zagazig, Egypt \\ Email: tagkomy@gmail.com, drsameh154@yahoo.com, *hosamgastro@yahoo.com
}

How to cite this paper: Abdalla, T.M., Monem, S.M.A. and Dawod, H.M. (2019) Value of Child-Turcotte-Pugh Score in Prediction of Treatment Response in "Difficult to Treat" Chronic HCV Cirrhotic Patients. Open Journal of Gastroenterology, 9, 211-222.

https://doi.org/10.4236/ojgas.2019.911024

Received: October 14, 2019

Accepted: November 18, 2019

Published: November 21, 2019

Copyright $\odot 2019$ by author(s) and Scientific Research Publishing Inc. This work is licensed under the Creative Commons Attribution International License (CC BY 4.0).

http://creativecommons.org/licenses/by/4.0/

(c) (i) Open Access

\begin{abstract}
Background and aim: The direct-acting antivirals (DAAs) treatment has greatly improved sustained virologic response (SVR) in chronic non-cirrhotic hepatitis $\mathrm{C}$ virus (HCV) patients and to less extent in those with cirrhosis. There is a stressing need for predicting the outcome of DAAs treatment especially in "difficult to treat" patients. This work aimed to study the value of the Child-Turcotte-Pugh (CTP) score in the prediction of treatment outcome with DAAs in "difficult to treat" chronic HCV patients. Materials and methods: A retrospective cohort study was conducted where files of 120 "difficult to treat" patients were randomly selected from the follow-up clinic. Patients' data were collected before and after treatment including history taking, clinical examination, laboratory investigations, and abdominal ultrasonography. Child-Turcotte-Pugh (CTP) scores were calculated. Results: There was no significant difference in mean Child score between patients with and without SVR before treatment, while this difference became significant after treatment. The patients without complications showed a highly significant decrease in their mean Child score after treatment, while patients with complications did not show any significant differences. Conclusion: The baseline Child-Turcotte-Pugh score cannot predict the treatment response of DAAs in "difficult to treat" chronic HCV patients, but it is significantly associated with the occurrence of complications.
\end{abstract}

\section{Keywords}

Hepatitis C, Child Score, Cirrhosis

\section{Introduction}

Hepatitis $\mathrm{C}$ virus (HCV) infection is a very dreadful widely but unevenly distri- 
buted global health problem. According to the World Health Organization (WHO), about 150 million people worldwide are already infected with HCV [1]. Chronic HCV infection can be complicated with liver cirrhosis and eventual further complications including liver decompensation, end-stage liver disease and hepatocellular carcinoma (HCC) stressing the need for liver transplantation. Chronic HCV is also associated with an increased risk of liver-related mortality [2] [3] [4].

Many therapeutic trials were conducted over more than two decades to achieve a sustained virologic response (SVR). SVR is reached when HCV-RNA becomes undetectable 12 weeks after the end of treatment (SVR12). Achieving SVR is associated with a decrease in the incidence of liver cancer (HCC) and improved survival in HCV patients whether cirrhotic or non-cirrhotic [5] [6] [7]. The recent direct-acting antiviral agents (DAAs) have markedly improved the SVR rates and gave a great therapeutic chance to a wide category of patients including those with contraindications or low SVR rates to Peg-IFN based antiviral therapy regimens [8] [9]. However, a great concern is still present about some patients showing a marked deterioration of liver function in spite of effective viral clearance. In such patients, the prediction of benefits of DAAs was not duly established so the outcome of treatment was not satisfactory. In this situation, the evaluation of predictors of treatment outcome is mandatory to allow such difficult-to-treat patients making the greatest benefit of treatment, not only by viral eradication but also by significant improving hepatic function [10] [11].

Various host and viral factors were implicated for the prediction of treatment outcome of $\mathrm{HCV}$ infection especially with the recent emergence of the pan-genotypic oral DAAs. Multiple variables such as age, gender, race, insulin resistance, body mass index, steatosis, advanced fibrosis stage, viral load, and HCV genotype were tried with interferon-based therapies for prediction of treatment outcome. They were found to be associated with non-response to therapy. However, these predictive variables may be not such important with DAAs as they were before with interferon [12] [13] [14] [15]. Other sets of suggested predictive variables, such as age, Child-Turcotte-Pugh (CTP) score, and platelet count, were tried with oral DAAs. Some authors considered CTP score as a system for deciding the strength of treatment, predicting the prognosis, deciding the necessity for liver transplantation and survival rate in chronic liver disease, mainly cirrhosis. The CTP score adopts multiple variables including serum albumin level, serum bilirubin level, ascites, hepatic encephalopathy and the International Normalizing Ratio (INR). Old age, CTP class B, low platelet count, and cirrhosis were found to be associated with non-response to DAAs therapy [16] [17]. Other studies were conducted using CPT score to assess the outcome of DAAS in HCV cirrhotic patients yet failing to prove a well-defined predicting ability of that score [16] [17] [18]. The aim of this work was to study the value of Child-Turcotte-Pugh score in the reliable prediction of treatment outcome with DAAs in "difficult to treat" chronic HCV patients. 


\section{Patients and Methods}

A retrospective cohort study was conducted at Tropical Medicine Department, Zagazig University Hospitals from May 2018 to December 2018. This study was conducted on 120 "difficult to treat" chronic HCV cirrhotic patients. The files of the patients were selected randomly from the follow-up clinic until the completion of the sample size. The sample size was decided according to the Institutional Review Board (IRB) and statistical specialists

\section{Inclusion criteria:}

Patients were selected according to the Supreme Council and the National Committee for Control of Viral Hepatitis (NCCVH) updated treatment protocol December 2016 [19]:

- HCV RNA positivity.

- Age $\geq 18$ years.

Selection of "difficult to treat" HCV Patient including one or more of the following criteria:

- Serum albumin $\leq 3.5 \mathrm{~g} / \mathrm{dl}$

- PEG-IFN treatment-experienced.

- Child A and B classes.

- Total serum bilirubin $\geq 1.2 \mathrm{mg} / \mathrm{dl}$.

- $\quad$ INR $\geq 1.2$.

- Platelet $<150,000 / \mathrm{mm}^{3}$.

Exclusion criteria:

Patients were excluded if they have one or more of these criteria:

- Child C cirrhotic patients (Child score $\geq 10$ )

- Pregnancy or inability to use effective contraception.

- Inadequately controlled diabetes mellitus (HA1C >9).

- Platelet count $<50,000 / \mathrm{mm}^{3}$

- HCC, except 6 months after intervention aiming at a cure with no evidence of activity by dynamic imaging (CT or MRI).

- Extra-hepatic malignancy except after two years of disease-free interval.

\section{Methods:}

The patients had been already treated by Sofosbuvir $(400 \mathrm{mg}) /$ day + Daclatas$\operatorname{vir}(60 \mathrm{mg}) /$ day + Ribavirin for 12 weeks. The starting dose of ribavirin is 600 $\mathrm{mg} /$ day. Trials were done to reach a dose of $1000 \mathrm{mg} /$ day based on individual patient tolerability. The data of all patients were collected twice, before treatment and the 12 weeks after the end of treatment. The data included:

- Detailed history taking and clinical examination.

- Laboratory investigations including Complete blood count (CBC), alanine aminotransferase (ALT), aspartate aminotransferase (AST), total bilirubin, serum albumin, alpha-fetoprotein, international normalized ratio (INR), serum creatinine and HCV RNA PCR.

- Abdominal ultrasonography.

- Child-Turcotte-Pugh score was calculated pre and post-treatment according to Table 1. 
Table 1. Child-Pugh scoring system.

\begin{tabular}{cccc}
\hline & \multicolumn{3}{c}{ Child-Turcotte-Pugh score } \\
\hline \multirow{2}{*}{ Measurements } & \multicolumn{3}{c}{ Score } \\
\cline { 2 - 4 } & None & 2 & 3 \\
\hline Encephalopathy & None & Grade I-II & Grade III-IV \\
Ascites & $1-2$ & Mild & Moderate to tense \\
Bilirubin (mg/dL) & $>3.5$ & $2-3$ & $>3$ \\
Albumin (g/dL) & $<1.7$ & $2.8-3.5$ & $<2.8$ \\
INR & $1.7-2.20$ & $>2.20$ \\
Class A: $5-6$ points; Class B: 7 - 9 points; Class C: $10-15$ points (17).
\end{tabular}

\section{Statistical Analysis}

Data were checked, entered and analyzed using SPSS 15 for Windows. Data were expressed as mean \pm SD for the quantitative variable, number, and percentage for qualitative one. Chi-square $\left(\mathrm{X}^{2}\right)$ or t-test, paired t-test, McNemar's test or Stuart-Maxwell test were used when appropriate. $\mathrm{P}<0.05$ was considered significant. $\mathrm{P}<0.001$ was considered highly significant.

\section{Results}

A total number of 120 patients who were categorized as "difficult to treat" were included in this retrospective cohort study. Their files were selected randomly from the follow-up clinic until the completion of the sample size from May 2018 to December 2018.

Males:females' ratio was about $59.2 \%: 40.8 \%$ of patients. The mean age was about 50.52 years and $10.8 \%$ only had prior HCV treatment. Their mean AFP and HCV RNA levels were $23.8 \mathrm{ng} / \mathrm{ml}$ and 6.25 million $\mathrm{IU} / \mathrm{ml}$ respectively (Table 2).

After treatment, there was a highly significant decrease in the following lab measurements; $\mathrm{Hb}$, WBCs, ALT, AST and TSB, while S. albumin significantly increased. However, others showed no significant changes (Table 3).

After treatment, $94.16 \%$ of patients showed SVR and $94.16 \%$ did not show any complications. Seven patients (5.83\%) were complicated by variceal bleeding (2 cases), grade 2 hepatic encephalopathy ( 2 cases) and 3 cases show HCC after treatment (Table 4).

There was a highly significant upgrading of Child classes in patients with SVR where Child classes were changed from B to A after treatment in about $21.2 \%$ of patients. On the other hand, Child classes were not affected by treatment in patients without SVR (Table 5).

There was a non- significant difference in mean Child score between patients with and without SVR before treatment, while this difference became significant after treatment. There was a highly significant decrease in the mean Child score in patients with SVR and an unchanged score of patients without SVR after 
Table 2. Basic characteristics of the studied patients.

\begin{tabular}{|c|c|c|}
\hline \multirow{2}{*}{ Demographic data } & \multicolumn{2}{|c|}{ All patients $(\mathrm{N}=120)$} \\
\hline & No. & $\%$ \\
\hline \multicolumn{3}{|l|}{ Gender } \\
\hline Male & 71 & $59.2 \%$ \\
\hline Female & 49 & $40.8 \%$ \\
\hline \multicolumn{3}{|l|}{ Age (years) } \\
\hline Mean \pm SD & \multicolumn{2}{|c|}{$50.52 \pm 8.48$} \\
\hline Median (range) & \multicolumn{2}{|c|}{$54(29-67)$} \\
\hline \multicolumn{3}{|l|}{ AFP (ng/ml) } \\
\hline Mean \pm SD & \multicolumn{2}{|c|}{$23.80 \pm 18.40$} \\
\hline Median (range) & \multicolumn{2}{|c|}{$16(9-97)$} \\
\hline \multicolumn{3}{|l|}{ HCV RNA $\left(\times 10^{6} \mathrm{iu} / \mathrm{ml}\right)$} \\
\hline Mean \pm SD & \multicolumn{2}{|c|}{$6.25 \pm 4.17$} \\
\hline Median (range) & \multicolumn{2}{|c|}{$7(1-17)$} \\
\hline \multicolumn{3}{|l|}{ Prior HCV treatment } \\
\hline No & 107 & $89.2 \%$ \\
\hline Yes & 13 & $10.8 \%$ \\
\hline
\end{tabular}

AFP: Alpha feto protein.

Table 3. Comparison between pre-treatment and post-treatment laboratory results among the studied patients.

\begin{tabular}{|c|c|c|c|c|}
\hline Laboratory results & $\begin{array}{l}\text { Pre-treatment } \\
\quad(\mathrm{N}=120)\end{array}$ & $\begin{array}{l}\text { Post-treatment } \\
\quad(\mathrm{N}=120)\end{array}$ & Test $^{\ddagger}$ & p-value \\
\hline \multicolumn{5}{|l|}{ Hemoglobin $(\mathrm{g} / \mathrm{dl})$} \\
\hline $\begin{array}{c}\text { Mean } \pm \text { SD } \\
\text { Median (range) }\end{array}$ & $\begin{array}{c}11.83 \pm 1.35 \\
12.80(10-15)\end{array}$ & $\begin{array}{c}11.19 \pm 1.24 \\
12(9-14.40)\end{array}$ & -6.208 & $\begin{array}{c}<0.001 \\
(\mathrm{HS})\end{array}$ \\
\hline \multicolumn{5}{|l|}{ WBCs $\left(\times 10^{3} / \mathrm{mm}^{3}\right)$} \\
\hline $\begin{array}{c}\text { Mean } \pm \text { SD } \\
\text { Median (range) }\end{array}$ & $\begin{array}{c}6.11 \pm 2.18 \\
6(3-11)\end{array}$ & $\begin{array}{c}5.91 \pm 2.03 \\
5.20(2.70-10)\end{array}$ & -3.109 & $\begin{array}{c}0.002^{*} \\
(\mathrm{~S})\end{array}$ \\
\hline \multicolumn{5}{|l|}{ Plt count $\left(\times 10^{3} / \mathrm{mm}^{3}\right)$} \\
\hline $\begin{array}{c}\text { Mean } \pm \text { SD } \\
\text { Median (range) }\end{array}$ & $\begin{array}{l}100.18 \pm 26.18 \\
100(51-149)\end{array}$ & $\begin{array}{r}100.84 \pm 30.26 \\
30.26(42-170)\end{array}$ & -0.368 & $\begin{array}{l}0.713 \\
(\mathrm{NS})\end{array}$ \\
\hline \multicolumn{5}{|l|}{ AST (IU/L) } \\
\hline $\begin{array}{c}\text { Mean } \pm \text { SD } \\
\text { Median (range) }\end{array}$ & $\begin{array}{c}46.17 \pm 20.22 \\
41(12-98)\end{array}$ & $\begin{array}{c}36.25 \pm 12.56 \\
35(12-78)\end{array}$ & -5.469 & $\begin{array}{l}<0.001 \\
(\mathrm{HS})^{* *}\end{array}$ \\
\hline \multicolumn{5}{|l|}{$\operatorname{ALT}(\mathrm{IU} / \mathrm{L})$} \\
\hline $\begin{array}{c}\text { Mean } \pm \text { SD } \\
\text { Median (range) }\end{array}$ & $\begin{array}{l}38.56 \pm 18.99 \\
37.2(13-80)\end{array}$ & $\begin{array}{l}30.61 \pm 13.29 \\
29.1(11-80)\end{array}$ & -3.959 & $\begin{array}{l}<0.001 \\
(\mathrm{HS})^{* *}\end{array}$ \\
\hline
\end{tabular}




\section{Continued}

\begin{tabular}{|c|c|c|c|c|}
\hline TSB (mg/dl) & & & & \multirow[b]{2}{*}{$\begin{array}{l}<0.001 \\
(\mathrm{HS})^{* *}\end{array}$} \\
\hline $\begin{array}{c}\text { Mean } \pm \text { SD } \\
\text { Median (range) }\end{array}$ & $\begin{array}{c}2.22 \pm 0.52 \\
2.19(1.06-3.37)\end{array}$ & $\begin{array}{c}1.98 \pm 0.51 \\
1.80(1.20-3.70)\end{array}$ & -4.400 & \\
\hline \multicolumn{5}{|l|}{ Albumin (g/dl) } \\
\hline $\begin{array}{c}\text { Mean } \pm \text { SD } \\
\text { Median (range) }\end{array}$ & $\begin{array}{c}3.33 \pm 0.24 \\
3.26(2.80-4.20)\end{array}$ & $\begin{array}{c}3.45 \pm 0.27 \\
3.40(2.90-4.20)\end{array}$ & -6.975 & $\begin{array}{l}<0.001 \\
(\mathrm{HS})^{* \star}\end{array}$ \\
\hline \multicolumn{5}{|l|}{ INR } \\
\hline $\begin{array}{c}\text { Mean } \pm \text { SD } \\
\text { Median (range) }\end{array}$ & $\begin{array}{c}1.34 \pm 0.13 \\
1.29(1.01-1.62)\end{array}$ & $\begin{array}{c}1.32 \pm 0.10 \\
1.22(1-1.71)\end{array}$ & -1.769 & $\begin{array}{l}0.077 \\
\text { (NS) }\end{array}$ \\
\hline \multicolumn{5}{|c|}{ Serum creatinine $(\mathrm{mg} / \mathrm{dl})$} \\
\hline $\begin{array}{c}\text { Mean } \pm \text { SD } \\
\text { Median (range) }\end{array}$ & $\begin{array}{c}1.25 \pm 0.13 \\
1.32(1-1.50)\end{array}$ & $\begin{array}{c}1.25 \pm 0.12 \\
1.31(1-1.60)\end{array}$ & -0.362 & $\begin{array}{l}0.717 \\
(\mathrm{NS})\end{array}$ \\
\hline \multicolumn{5}{|c|}{$\begin{array}{l}\text { *Wilcoxon signed ranks test. }{ }^{*} \text { significant. NS: non-significant. }{ }^{* *} \text { Highly significant. Plt: platelets. WBCs: whit } \\
\text { blood cells. ALT: Alanine aminotransferase. AST: Asparatae aminotransferase. TBS: total serum bilirubin. }\end{array}$} \\
\hline \multirow{2}{*}{\multicolumn{2}{|c|}{ Outcome of treatment }} & \multicolumn{2}{|c|}{ All patients $(\mathrm{N}=120)$} & \\
\hline & & No. & $\%$ & \\
\hline \multicolumn{5}{|c|}{ SVR } \\
\hline \multicolumn{2}{|l|}{ No } & 7 & \multicolumn{2}{|l|}{$5.83 \%$} \\
\hline \multicolumn{2}{|c|}{ Yes } & 113 & \multicolumn{2}{|l|}{$94.16 \%$} \\
\hline \multicolumn{5}{|c|}{ Complications } \\
\hline \multicolumn{2}{|l|}{ No } & 113 & \multicolumn{2}{|l|}{$94.16 \%$} \\
\hline \multicolumn{2}{|c|}{ Yes } & 7 & \multicolumn{2}{|l|}{$5.83 \%$} \\
\hline
\end{tabular}

SVR: sustained virologic response.

Table 5. Comparison between patients with and without SVR as regard pre- and post-treatment Child class.

\begin{tabular}{|c|c|c|c|c|c|c|}
\hline \multirow{2}{*}{ Child score } & \multicolumn{2}{|c|}{ With SVR $(N=113)$} & \multicolumn{2}{|c|}{ Without SVR $(N=7)$} & \multirow{2}{*}{ Test $^{\ddagger}$} & \multirow{2}{*}{$\mathrm{P}$-value } \\
\hline & No. & $\%$ & No & $\%$ & & \\
\hline \multicolumn{7}{|c|}{ Pre-treatment class } \\
\hline Child A & 62 & $54.9 \%$ & 3 & $42.9 \%$ & \multirow{2}{*}{0.408} & \multirow{2}{*}{$\begin{array}{l}0.659 \\
(\mathrm{NS})\end{array}$} \\
\hline Child B & 51 & $45.1 \%$ & 4 & $57.1 \%$ & & \\
\hline \multicolumn{7}{|c|}{ Post-treatment class } \\
\hline Child A & 86 & $76.1 \%$ & 3 & $42.9 \%$ & \multirow{2}{*}{3.081} & \multirow{2}{*}{$\begin{array}{l}0.112 \\
(\mathrm{NS})\end{array}$} \\
\hline Child B & 27 & $23.9 \%$ & 4 & $57.1 \%$ & & \\
\hline Test $^{*}$ & \multicolumn{2}{|c|}{16.056} & \multicolumn{2}{|c|}{1.000} & & \\
\hline P-value & \multicolumn{2}{|c|}{$<0.001^{\star *}$} & \multicolumn{2}{|c|}{0.317 (NS) } & & \\
\hline
\end{tabular}

${ }^{*}$ Chi-square test. ${ }^{*}$ McNemar's test. NS: non-significant. ${ }^{*}$ highly significant. SVR: sustained virologic response. 
treatment (Table 6).

The mean Child score showed a significant difference between patients with and without complications before treatment and a highly significant difference after treatment. The patients without complications showed highly significant decrease in their mean Child score after treatment, while patients with complications did not show any significant differences (Table 7).

\section{Discussion}

Egypt has the highest worldwide prevalence of HCV [20]. Genotype 4 represents the most common genotype of HCV in Egypt accounting for about $93 \%$ of the burden of HCV infection [21]. A dramatic change has evolved in the treatment of HCV after the introduction of DAAs shifting the treatment of chronic HCV to a new level of effective potency and high safety [22]. DAAs were useless in some patients and others have been deteriorated or even died on treatment. Therefore, prediction of the outcome of DAAs treatment is a fundamental step

Table 6. Comparison between patients with and without SVR as regard pre- and post-treatment Child score's mean.

\begin{tabular}{ccccc}
\hline Child score & With SVR $(\mathrm{N}=113)$ & Without SVR $(\mathrm{N}=7)$ & Test $^{\ddagger}$ & P-value \\
\hline Pre-treatment score & & & & \\
Mean \pm SD & $6.62 \pm 0.79$ & $7.21 \pm 1.31$ & -1.091 & 0.275 \\
Median (range) & $7(6-9)$ & $6(6-9)$ & & \\
Post-treatment score & & & & \\
Mean \pm SD & $6.14 \pm 0.92$ & $7.19 \pm 1.29$ & -2.004 & $0.045^{\star}$ \\
Median (range) & $7(5-9)$ & $6(6-9)$ & & \\
Test & -5.758 & 1.000 & & \\
P-value & $<0.001^{\star *}$ & $0.317(\mathrm{NS})$ & & \\
\hline
\end{tabular}

*Significant. ${ }^{*}$ highly significant. NS: non- significant. ${ }^{*}$ Mann Whitney U test. ${ }^{\sharp}$ Wilcoxon signed ranks test.

Table 7. Comparison between patients with and without complications as regard pre-and post-treatment Child score's mean.

\begin{tabular}{ccccc}
\hline Child score & $\begin{array}{c}\text { Without complication } \\
(\mathbf{N}=113)\end{array}$ & $\begin{array}{c}\text { With complications } \\
(\mathbf{N}=7)\end{array}$ & Test $^{\ddagger}$ & P-value \\
\hline Pre-treatment & $6.54 \pm 0.71$ & $8.21 \pm 0.82$ & -3.467 & $0.001^{*}$ \\
Mean \pm SD & $6(6-9)$ & $8(7-9)$ & & \\
Median (range) & & & & \\
Post-treatment & $6.07 \pm 0.81$ & $8.41 \pm 0.88$ & -3.771 & $<0.001^{* *}$ \\
Mean \pm SD & $6(5-8)$ & $9(7-9)$ & & \\
Median (range) & -5.962 & -1.000 & & \\
Test & $<0.001^{* *}$ & 0.317 (NS) & & \\
P-value (Sig.) & &
\end{tabular}

**highly significant. ${ }^{*}$ significant; NS: non-significant. ${ }^{*}$ Mann Whitney U test. " Wilcoxon signed ranks test. 
to make sure that SVR and clearance of HCV will be achieved not only effectively but also safely [23] [24].

This work aims to study the value of Child-Turcotte-Pugh score in the reliable prediction of treatment outcome with DAAs in "difficult to treat" chronic HCV patients.

In this study, the course of treatment resulted in an overall $94.16 \%$ achievement of sustained virologic response at week 12 (SVR12) with $100 \%(n=13)$ for treatment-experienced (interferon and ribavirin for 48 weeks) patients. This result agrees with many Egyptian and American studies, which confirm the efficacy of DAAs in the management of HCV in Egypt [25] [26] [27] [28]. However, the reported SVR12 of treatment-experienced patients is higher than other studies, which may be because some patients who included were Child A who usually obtain significantly higher SVR than Child B/C [29].

Hemoglobin level decreased significantly at weeks 12 after treatment but there was no requirement for dose reduction or stopping treatment. This coincides with the results of Deterding et al. who reported a decrease in baseline hemoglobin during treatment by almost $2 \mathrm{~g} / \mathrm{dL}$. Ribavirin and DAAs can cause anemia as a side effect [30].

In this study, there was a significant reduction in AST and ALT level and improvement of liver function parameters including albumin and bilirubin are improved in the majority of patients. These results agree with those of Deterding et al., Mehta et al. and Charlton et al. where they studied different genotypes with different combinations of DAAs at week 12 [30] [31] [32]. These results prove the role of DAAs' in improving necro-inflammation in patients with chronic HCV infection.

The SVR 12 rates describe the virologic response, while changes in CTP score describe the clinical response seen in patients 12 weeks after the end of treatment. In this study, there was a highly significant upgrading of Child class B to A in about $21.2 \%$ of patients with SVR. This result is quite consistent with that of Deterding et al. who recorded improving CPT scores in $25 \%$ of studied patients [30].

In this study, before treatment, mean Child score in patients who reported complications during the treatment $(8.2 \pm 0.8)$ was significantly higher when compared with patients without complications $(6.5 \pm 0.7)$ indicating that the high Child score is a good predictor of the occurrence of complication. However, because of the small number of patients with complications $(n=7)$, the exact predictive cut off value of Child score cannot be calculated by the specific statistical tests used for this purpose. This result agrees to some extent with that of Manns et al. who observed that the patients with baseline MELD score $<15$ reported more improvement of their MELD and Child scores after treatment and rarely develop complications unlike those with baseline MELD score $\geq 15$ [33].

After treatment, three cases of hepatocellular carcinoma (HCC) were reported in this study. This result agrees with that of Deterding et al. with DAAs induced 
SVR - and Van der Meer et al. but with interferon-induced SVR. These results prove that although DAAs may improve liver function parameters in chronic HCV patients, HCC may still develop [30] [31] [32] [33] [34]. These finding stresses the need for careful monitoring for HCC even if HCV RNA is negative.

In the current study, before treatment, mean Child score in patients who achieved SVR did not show a significant difference when compared with patients who did not achieve SVR indicating that the scores cannot be used as predictors of response to DAAs. This result is not matching with that of Carrillo et al. (2017) who reported that decompensated cirrhosis (CTP B/C) at baseline was associated with lower rates of virologic response compared with patients with less advanced cirrhosis (CTP A) [28]. The limitations in our study included small sample size, exclusion of patients with Child score $\geq 10$ as those patients are managed in a higher tertiary center with more facilities.

\section{Conclusion}

The baseline Child-Turcotte-Pugh score cannot predict the treatment response of DAAs in "difficult to treat" chronic HCV patients, but it is significantly associated with the occurrence of complications.

\section{Ethical Approval}

The research protocol was approved by the Institutional Review Board (IRB), the ethical committee of University Hospitals.

\section{Funding}

None.

\section{Conflicts of Interest}

The authors declare no conflicts of interest regarding the publication of this paper.

\section{References}

[1] WHO (2014) Hepatitis C: Fact Sheet N 164.

[2] Davis, G.L., Albright, J.E., Cook, S.F. and Rosenberg, D.M. (2003) Projecting Future Complications of Chronic Hepatitis C in the United States. Liver Transplantation, 9, 331-338. https://doi.org/10.1053/jlts.2003.50073

[3] El-Serag, H.B. and Mason, A.C. (1999) Rising Incidence of Hepatocellular Carcinoma in the United States. The New England Journal of Medicine, 340, 745-750. https://doi.org/10.1056/NEJM199903113401001

[4] Verna, E.C. and Brown Jr., R.S. (2006) Hepatitis C Virus and Liver Transplantation. Clinical Liver Disease, 10, 919-940. https://doi.org/10.1016/j.cld.2006.08.012

[5] Velosa, J., Serejo, F., Marinho, R., Nunes, J. and Glória, H. (2011) Eradication of Hepatitis C Virus Reduces the Risk of Hepatocellular Carcinoma in Patients with Compensated Cirrhosis. Digestive Diseases and Sciences, 56, 1853-1861. https://doi.org/10.1007/s10620-011-1621-2 
[6] Van der Meer, A.J., Wedemeyer, H., Feld, J.J., Dufour, J.F., Zeuzem, S., Hansen, B.E. and Janssen, H.L. (2014) Life Expectancy in Patients with Chronic HCV Infection and Cirrhosis Compared with a General Population. JAMA, 312, 1927-1928. https://doi.org/10.1001/jama.2014.12627

[7] Hsu, C.S., Chao, Y.C., Lin, H.H., Chen, D.S. and Kao, J.H. (2015) Systematic Review: Impact of Interferon-Based Therapy on HCV-Related Hepatocellular Carcinoma. Scientific Reports, 5, Article No. 9954. https://doi.org/10.1038/srep09954

[8] Welzel, T.M., Dultz, G. and Zeuzem, S. (2014) Interferon-Free Antiviral Combination Therapies without Nucleosidic Polymerase Inhibitors. Journal of Hepatology, 61, S98-S107. https://doi.org/10.1016/j.jhep.2014.08.014

[9] Han, D.S., Hahm, B., Rho, H.M. and Jang, S.K. (1995) Identification of the Protease Domain in NS3 of Hepatitis C Virus. Journal of General Virology, 76, 985-993.

https://doi.org/10.1099/0022-1317-76-4-985

[10] Foster, G.R., Irving, W.L., Cheung, M.C., Walker, A.J., Hudson, B.E., Verma, S., McLauchlan, J., Mutimer, D.J., Brown, A., Gelson, W.T., et al. (2016) Impact of Direct-Acting Antiviral Therapy in Patients with Chronic Hepatitis C and Decompensated Cirrhosis. Journal of Hepatology, 64, 1224-1231.

https://doi.org/10.1016/j.jhep.2016.01.029

[11] Steinebrunner, N., Stein, K., Sandig, C., Bruckner, T., Stremmel, W. and Pathil, A. (2018) Predictors of Functional Benefit of Hepatitis C Therapy in a "Real-Life" Cohort. World Journal of Gastroenterology, 24, 852-861. https://doi.org/10.3748/wjg.v24.i7.852

[12] Cavalcante, L.N. and Lyra, A.C. (2015) Predictive Factors Associated with Hepatitis C Antiviral Therapy Response. World Journal of Hepatology, 7, 1617-1631. https://doi.org/10.4254/wjh.v7.i12.1617

[13] Afdhal, N.H., McHutchison, J.G., Zeuzem, S., et al. (2011) Hepatitis C Pharmacogenetics: State of the Art in 2010. Hepatology, 53, 336-345. https://doi.org/10.1002/hep.24052

[14] Hadziyannis, S.J., Sette, H., Morgan, T.R., et al. (2004) Peginterferon Alpha 2a and Ribavirin Combination Therapy in Chronic Hepatitis C: A Randomized Study of Treatment Duration and Ribavirin Dose. Annals of Internal Medicine, 140, 346-355. https://doi.org/10.7326/0003-4819-140-5-200403020-00010

[15] Manns, M.P., Wedemeyer, H. and Cornberg, M. (2006) Treating Viral Hepatitis C: Efficacy, Side Effects, and Complications. Gut, 55, 1350-1359. https://doi.org/10.1136/gut.2005.076646

[16] Ahmed, O.A., Elsebaey, M.A., Fouad, M.H.A., Elashry, H., Elshafie, A.I., Elhadidy, A.A., Esheba, N.E., Elnaggar, M.H., Soliman, S. and Abd-Elsalam, S. (2018) Outcomes and Predictors of Treatment Response with Sofosbuvir plus Daclatasvir with or without Ribavirin in Egyptian Patients with Genotype 4 Hepatitis C Virus Infection. Infection and Drug Resistance, 11, 441-445. https://doi.org/10.2147/IDR.S160593

[17] Cholongitas, E., Papatheodoridis, G.V., Vangeli, M., Terreni, N., Patch, D. and Burroughs, A.K. (2005) Systematic Review: The Model for End-Stage Liver Disease-Should It Replace Child-Pugh's Classification for Assessing Prognosis in Cirrhosis? Alimentary Pharmacology \& Therapeutics, 22, 1079-1089. https://doi.org/10.1111/j.1365-2036.2005.02691.x

[18] Saxena, V., Nyberg, L., Pauly, M., Dasgupta, A., Nyberg, A., Piasecki, B., Winston, B., Redd, J., Ready, J. and Terrault, N. (2015) Safety and Efficacy of Simeprevir/Sofosbuvir in Hepatitis C Infected Patients with Compensated and Decompen- 
sated Cirrhosis. Hepatology, 62, 715-725. https://doi.org/10.1002/hep.27922

[19] El-Akel, W., El-Sayed, M.H., El Kassas, M., et al. (2017) National Treatment Programme of Hepatitis C in Egypt: Hepatitis C Virus Model of Care. Journal of Viral Hepatitis, 24, 262-267. https://doi.org/10.1111/jvh.12668

[20] Ahmed, O.A., Kaisar, H.H., Hawash, N., et al. (2017) Efficacy of Sofosbuvir plus Ribavirin with or without Peginterferon-Alfa in Treatment of a Cohort of Egyptian Patients with Hepatitis C Virus Infection. Infectious Disorders Drug Targets, 17, 95-100. https://doi.org/10.2174/1871526517666170417143216

[21] AbdElrazek, A.E., Bilasy, S.E., Elbanna, A.E., et al. (2014) Prior to the Oral Therapy, What Do We Know about HCV-4 in Egypt: A Randomized Survey of Prevalence and Risks Using Data Mining Computed Analysis. Medicine (Baltimore), 93, e204. https://doi.org/10.1097/MD.0000000000000204

[22] Pol, S., Corouge, M. and vallet-Pichard, A. (2016) Daclatasvir-Sofosbuvir Combination Therapy with or without Ribavirin for Hepatitis C Virus Infection: From the Clinical Trials to Real Life. Hepatic Medicine, 8, 21-26.

https://doi.org/10.2147/HMER.S62014

[23] Carrion, A.F., Khaderi, S.A. and Sussman, N.L. (2016) Model for End-Stage Liver Disease Limbo, Model for End-Stage Liver Disease Purgatory, and the Dilemma of Treating Hepatitis C in Patients Awaiting Liver Transplantation. Liver Transplantation, 22, 279-280. https://doi.org/10.1002/lt.24383

[24] El-Sherif, El-Raziky, El-Akel, W., et al. (2018) Planning and Prioritizing Direct-Acting Antivirals Treatment for HCV Patients in Countries with Limited Resources: Lessons from the Egyptian Experience. Journal of Hepatology, 23, 235-244.

[25] Omar, H., Elakel, W., Elbaz, T., et al. (2017) Generic Daclatasvir plus Sofosbuvir, with or without Ribavirin, in Treatment of Chronic Hepatitis C: Real-World Results from 18378 Patients in Egypt. Alimentary Pharmacology \& Therapeutics, 1, 11-47. https://doi.org/10.1111/apt.14428

[26] Wahsh, E.A., Hussein, A.K., Gomaa, A.A., et al. (2018) Real Life Egyptian Experience of Daclatasvir plus Sofosbuvir with Ribavirin in Naïve Difficult to Treat HCV Patients. Infectious Disorders Drug Targets, 18, 1.

[27] Ahmed, O.A., Elsebaey, M.A., Fouad, M.H., et al. (2018) Outcomes and Predictors of Treatment Response with Sofosbuvir plus Daclatasvir with or without Ribavirin in Egyptian Patients with Genotype 4 Hepatitis C Virus Infection. Infection and Drug Resistance, 11, 441-445. https://doi.org/10.2147/IDR.S160593

[28] Sulkowski, M.S., Gardiner, D.F., Rodriguez-Torres, M., et al. (2014) Daclatasvir plus Sofosbuvir for Previously Treated or Untreated Chronic HCV Infection. The New England Journal of Medicine, 370, 211-221. https://doi.org/10.1056/NEJMx140011

[29] Carrillo, C.F., Lens, S., Llop, E., et al. (2017) Treatment of Hepatitis C Virus Infection in Patients with Cirrhosis and Predictive Value of MELD: Analysis of Data from the Hepa-C Registry. Hepatology, 65, 1810-1822. https://doi.org/10.1002/hep.29097

[30] Deterding, K., Höner, Z.U., Siederdissen, C., et al. (2015) Improvement of Liver Function Parameters in Advanced HCV-Associated Liver Cirrhosis by IFN-Free Antiviral Therapies. Alimentary Pharmacology \& Therapeutics, 42, 889-901. https://doi.org/10.1111/apt.13343

[31] Mehta, K.M., Nandwani, B., et al. (2017) Safety and Efficacy of Sofosbuvir and Daclatasvir for Hepatitis C Virus Infection in Patients with $\beta$-Thalassemia Major. Journal of Clinical and Experimental Hepatology, 8, 1564-1566.

https://doi.org/10.1016/j.jceh.2017.06.002 
[32] Charlton, M., Gane, E., Manns, M.P., et al. (2015) Sofosbuvir and Ribavirin for Treatment of Compensated Recurrent Hepatitis C Virus Infection after Liver Transplantation. Gastroenterology, 148, 108-117. https://doi.org/10.1053/j.gastro.2014.10.001

[33] Manns, M., Samuel, D., Gane, E.J., et al. (2016) Ledipasvir and Sofosbuvir plus Ribavirin in Patients with Genotype 1 or 4 Hepatitis C Virus Infection and Advanced Liver Disease: A Multicentre, Open-Label, Randomized, Phase 2 Trial. The Lancet Infectious Diseases, 16, 685-697. https://doi.org/10.1016/S1473-3099(16)00052-9

[34] Van der Meer, A.J., Veldt, B.J., Feld, J.J., et al. (2014) Association between Sustained Virological Response and All-Cause Mortality among Patients with Chronic Hepatitis $\mathrm{C}$ and Advanced Hepatic Fibrosis. JAMA, 308, 2584-2593.

https://doi.org/10.1001/jama.2012.144878 